\title{
Development of resource-saving technologies for rice cultivation on rice irrigation systems in the Krasnodar Territory
}

\author{
Igor Prikhodko, Stanislav Vladimirov, and Daniil Alexandrov
}

Kuban State Agrarian University named after I.T. Trubilin, 13 Kalinin Str., Krasnodar, 350044, Russia

\begin{abstract}
According to the studies carried out by the US Geological Survey (USGS) under the project GFSAD30, Russia ranks fourth in the world in the number of fertile lands. However, today there are some problems that "slow down" the development of the Russia's agricultural sector, including the rice-planting complex. One of the main problems of the Russian agro-industrial complex is unsustainable environmental management, which leads to inefficiency and sometimes loss of agricultural production. This is caused by the "rigidity" of the legal framework, the reluctance or inability of the economy to switch to new resourcesaving technologies, as well as the fear of partially or completely losing the crop when switching to new technologies. For the "soft" transition of the economy to new resource-saving technologies, we propose a resource-saving technology for cultivating rice on underground drip irrigation under mulch film on rice irrigation systems, the introduction of which proved its effectiveness, as well as the relevance of our study. The efficiency of proposed resource-saving technology of rice cultivation on drip irrigation is expressed in the increase of profitability of rice production by $26 \%$, reduction of irrigation norm by more than 5 times, labor intensity of rice production by $42 \%$ and material costs by $24 \%$. The proposed technology not only reduced the anthropogenic load, but also improved the land reclamation condition, including the situation in the rice irrigation ecosystem. Further development of drip technologies in the rice sector of Russia will allow developing fundamentally new, ecological-reclamative, balanced rice crop rotation with the inclusion of vegetable and cucurbits crops. The proposed technology will provide an opportunity to cultivate rice outside rice irrigation systems on previously rich lands, which will give agro-industrial workers new opportunities and prospects in rice production.
\end{abstract}

\section{Introduction}

Currently, the Russian agro-industrial complex is facing a difficult situation, which is caused by the growing gap between the scientific and technical level and the existing production level $[1,2]$. Current political and economic conditions dictate their rules, which often do not meet modern requirements for agriculture [3, 4]. The growing shortage of water and soil resources, together with the growing demographic situation, are forcing agricultural producers to disrupt the production process in order to obtain additional crops [5, 6]. It is possible to correct this situation only by the creation of modern, high-precision, environmentally friendly resource-saving technologies for cultivating agricultural products. The most resource-intensive production is rice farming [7]. This is caused by the technological need to cultivate rice on rice irrigation systems with the creation of a water layer on rice bays, and is considered a traditional technology for cultivating rice in Russia [8].

To address this issue, the world's best practices to date should be used $[9,10]$. The analysis of existing modern rice cultivation technologies showed that the most efficient and modern technology is rice drip watering, which has been successfully used for more than 10 years in China [11-12]. In Russia, research on the introduction of rice cultivation technologies on drip irrigation in the Krasnodar Territory, Volgograd and Rostov regions was carried out by scientists: I.P. Kruzhilin, N.N. Dubenk M. A. Ganiev, K.A. Rodin and others [13-16], who proved the effectiveness of drip rice irrigation technologies in Russia.

The development of new or optimization of modern engineering irrigation systems already tested in Russia will allow accumulating sufficient production experience for the development of automated information and reference systems implemented in the form of software, which will be based on multilevel simulation models [17]. This solution will ensure that Russia reaches a new level in agricultural production, while not only guaranteeing Russia's food security, but also making it the leading exporter of high-quality agricultural products on the world market without reducing the agro-resource potential of agricultural land [18].

\section{Materials and methods}

The developed resource-saving technology for cultivating rice on drip watering under mulch film was tested at Chernoerkovskoye LLC in Slavyansky district of the Krasnodar Territory (Figures 1-3).

\footnotetext{
* Corresponding author: prihodkoigor2012@yandex.ru
} 

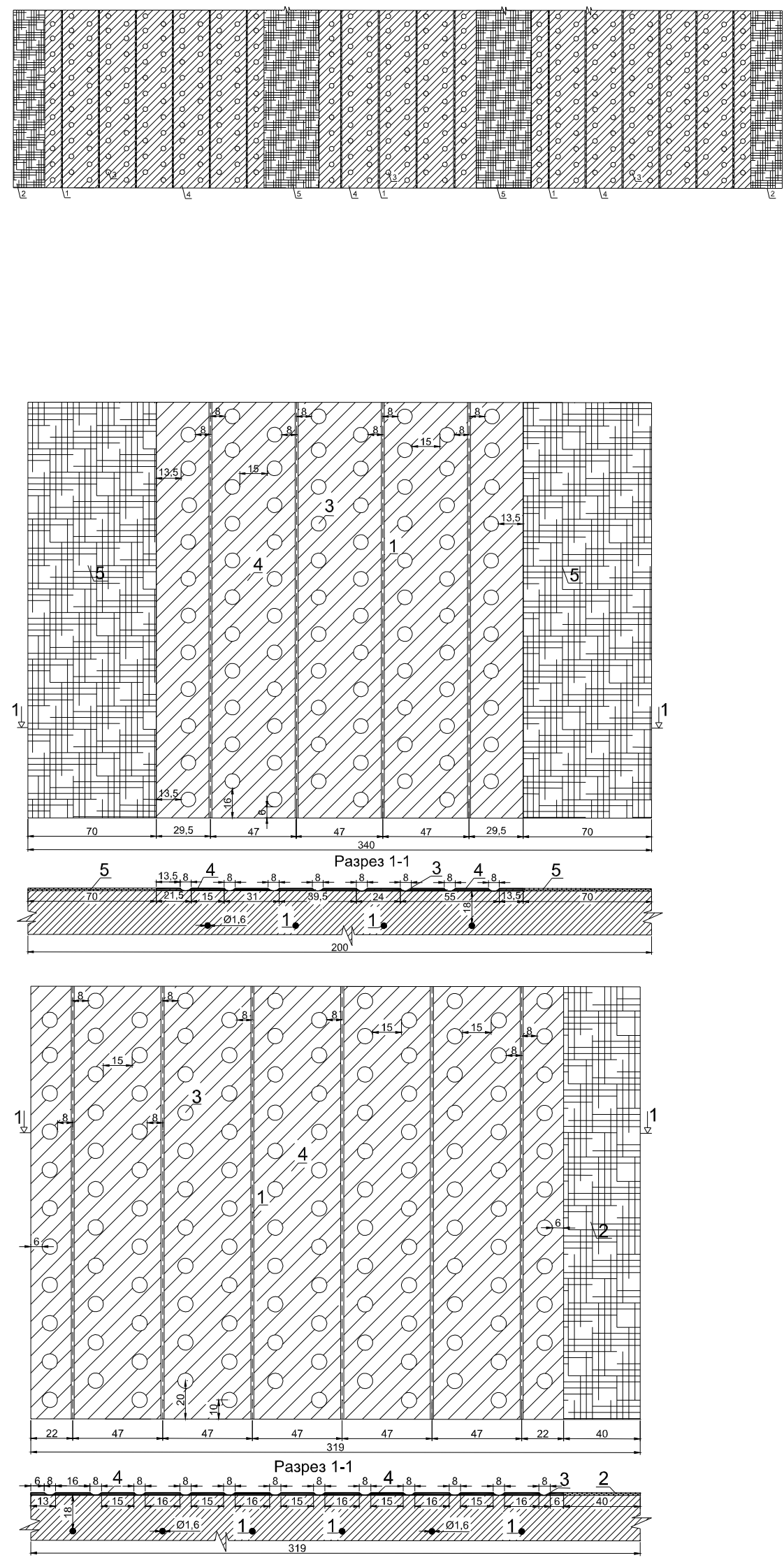

Figure 1. Flow diagram of one catch taking into account the technical characteristics of tillage and harvesting equipment in Chernoerkovskoye LLC of Slavyansky district of the Krasnodar Territory when cultivating rice and associated rice rotation crops on underground drip irrigation with underground drip hose and/or belt to a depth of $0.18 \mathrm{~m}$ under a mulch film, including a biodegradable film: 1 underground drip hose and/or belt; 2 service passage; 3 - round holes in a mulch film for crop planting; 4 - mulch film; 5 - service lane; 6 - row.

Figure 2. Fragment of the central part of the flow diagram of one catch taking into account the technical characteristics of tillage and harvesting equipment in Chernoerkovskoye LLC of Slavyansky district of the Krasnodar Territory when cultivating rice and associated rice rotation crops on underground drip irrigation with underground drip hose and/or belt to a depth of $0.18 \mathrm{~m}$ under a mulch film, including a biodegradable film: 1 underground drip hose and/or belt; 2 service passage; 3 - round holes in a mulch film for crop planting; 4 - mulch film; 5 - service lane; 6 - row.

Figure 3. Fragment of the right part of the flow diagram of one catch taking into account the technical characteristics of tillage and harvesting equipment in Chernoerkovskoye LLC of Slavyansky district of the Krasnodar Territory when cultivating rice and associated rice rotation crops on underground drip irrigation with underground drip hose and/or belt to a depth of $0.18 \mathrm{~m}$ under a mulch film, including a biodegradable film: 1 underground drip hose and/or belt; 2 service passage; 3 - round holes in a mulch film for crop planting; 4 - mulch film; 5 - service lane; 6 - row.
Rice production was carried out using ecologicaladaptive technology taking into account and optimizing all available farm resources from 2016 to 2019 in the following sequence:

In autumn, in the first year of the rice cultivation method on the lands of rice irrigated stock at underground drip irrigation under polyethylene and/or biodegradable mulch perforated film, preliminary, after the removal of the predecessor, there is a need to carry out one-time cutting and restoration of peripheral check 
grooves with the depth of 0.4-0.6 m, level the check surface, ensure main soil treatment to the depth of 0.25 $0.30 \mathrm{~m}$, clean irrigation and discharge channels, fill check rollers to design elevations, provide deep loosening (chiselling) to a depth of $0.16-0.18 \mathrm{~m}$, disk plowing with organic fertilizers to a depth of $0.10-0.12$ $\mathrm{m}$ with the application rate of 40-50 t per 1 ha of manure or green fertilizer.

In spring of the first year of the method there is a need to perform harrowing with toothed harrows in two tracks to a depth of $0.08 \mathrm{~m}$, and after that beds are formed by deepening in the form of inter-row service lanes and passages, which are covered with nonwoven geosynthetics. At the same time size and distance between seedbeds depend on technical characteristics of the method used for rice cultivation and associated rice rotation crops.

Then, the main line and underground hoses and/or drip watering belts are laid to the depth calculated taking into account the height of seedbed 6 and the depth of the root system of rice rotation crops for a period of up to eight years inclusive. Besides, the location of underground hoses and/or drip watering belts must not be lower than the bed base and not higher than the middle of the root system of rice crops, and not higher than the depth of soil treatment, the pitch between the water outlets of underground hoses and/or drip watering belts - $20 \mathrm{~cm}$, diameter and wall thickness of underground drop hose and/or belt $-16 \mathrm{~mm}$ and $0.9 \mathrm{~mm}$, respectively, wherein the water discharge of the underground drip hose and/or belt in $1 / \mathrm{h}$ per $1 \mathrm{~m}$ is taken on the condition of providing the required moisture in a given soil layer for rice crops. Moreover, the distance between underground drop hoses and/or belts is $47 \mathrm{~cm}$, and the underground drop hose and/or belt is laid in compliance with the condition of soil moistening in the root layer with one underground drop hose and/or belt of two perforation rows on the mulch film. The perforation diameter shall be $8 \mathrm{~cm}$ arranged $8 \mathrm{~cm}$ from the underground hose and/or drip belt laying axis and $12 \mathrm{~cm}$ in a row between adjacent perforations.

Then, annual spring-autumn technological cycle of works is performed, which includes the following:

- press work of ridge crests;

- growing rice seedlings in the amount of 1 to 4 plants in one nutrient pot with a diameter of $8 \mathrm{~cm}$, the components of its substrate: high-fertile field land, humus, peregrine, horse peat, coarse sand are taken in such a ratio that the content of humus in the substrate is not lower than $60 \%$, substrate density $-0.8-1.0 \mathrm{~g} / \mathrm{cm}^{3}$, porosity $-80-90 \%$, air content - at least $15-20 \%$ with addition of microelements to the substrate before planting rice seeds in the amount of $75 \%$ of the total norm of $\mathrm{N}_{150} \mathrm{P}_{60} \mathrm{~K}_{45}$ in $\mathrm{kg}$ of active agent/ha and one feeding with nitrogen fertilizers in the stage of 2-3 leaves with the norm of $\mathrm{N}_{40}$ in $\mathrm{kg}$ of active agent/ha, and maintenance of temperature mode during seedlings growth: during the day $24-26{ }^{\circ} \mathrm{C}$, in cloudy weather $20-22{ }^{\circ} \mathrm{C}$, at night $-18-20{ }^{\circ} \mathrm{C}$, optimal preirrigation moisture of the substrate at the level of $80 \%$ of the lowest moisture intensity, relative air humidity - 70-80 $\%$ and illumination: the first three days the time of supplementary lighting should be 24 hour, after the third day - at least 12-14 hours, depending on daylight hours and weather conditions;

- preirrigation before rice planting with the norm ensuring $90 \%$ of soil moisture content of the lowest moisture intensity in the layer of $0.6 \mathrm{~m}$;

- soil surface treatment with soil herbicides; covering the seedbed with a perforated mulch film;

- planting of rice seedlings into the perforation of the mulch film in a stage of 6-7 leaves with a green color, a well-developed root system and not infected with pests and diseases, while seedlings are sprayed with biologically active substances 1-2 days before planting rice seedlings in the open ground;

- drip watering of rice through the underground drip irrigation system during the growing season with the periodicity and rate of irrigation thus meeting the condition of ensuring constant soil moisture of $80 \%$ of the lowest moisture intensity in the layer of $0.4 \mathrm{~m}$;

- application of $25 \%$ of the total norm of mineral fertilizers by two equal norms $\mathrm{N}_{25} \mathrm{P}_{20} \mathrm{~K}_{15}$ in $\mathrm{kg}$ of active agent/ha to the stage of 8-9 leaves after full survival and to the stage of tillering by fertigation through the underground drip irrigation system, while the full norm may be adjusted from the recommended depending on the agricultural background and the adopted crop rotation;

- treatment of rice plants with pesticides in the stage of tillering, with biologically active substances at the end of the stage of tillering before booting; twice with fungicides in the booting stage and again after 20-25 days, with insecticides in the growing season when the pests exceed the economic threshold of harmfulness;

- rice harvesting;

- preirrigation before planting of associated rice rotation crops with the necessary and sufficient moisture for planting and soil moisture depth through the system of underground drip irrigation with the application of mineral fertilizers, the standards and deadlines for application of which are adopted in accordance with the accepted production technology;

- plant propagation and/or planting of associated rice rotation crops with the introduction of mineral fertilizers, treatment of crops with pesticides, fungicides and insecticides, the standards and deadlines for which are adopted in accordance with the adopted production technology;

- drip watering of rice rotation crops through the underground drip irrigation system during the growing season with the periodicity and rate of irrigation thus meeting the soil moisture in the soil layer for the normal development of crops according to the required production technology;

- harvesting of rice rotation crops followed by the collection of a mulch perforated film from seedbeds and, in case of biodegradable mulch film, it is left on the beds;

- two-track shallow plowing to a depth of 0.06-0.08 $\mathrm{m}$.

In spring, in subsequent years of rice cultivation, the seedbed geometry is restored with loosening of the upper ridge layer to a depth of $0.06-0.08 \mathrm{~m}$, after which the annual spring-autumn technological cycle is repeated. 


\section{Results and discussion}

The project of drip irrigation of rice under mulch film on a rice irrigation system was tested at Chernoerkovskoye LLC of Slavyansky district ( $2^{\text {nd }}$ branch) of the Krasnodar Territory on an area of 4.5 hectares (one rice check). The farm uses the scheme of the engineering rice section of the Krasnodar type. The cultivated rice crop was Rapan variety with rice being the predecessor in the first year of the method.

From 2016 to 2019 the following crop rotation was used on the experimental field: 2016: rice (seedlings) + cucurbits (seedlings); 2017: rice (seedlings) + chickpea (seed); 2018: rice (seedlings) + tomatoes (seedlings); 2019: rice (seedlings) + vetch (seed).

To implement the project, we used a simulation model of the economic justification of environmental measures on the rice irrigation system and a mathematical model of the optimal volume of planned measures [19-20], the use of which made it possible to develop an optimal adaptive technological map taking into account all available technological, energy, material, labor resources, as well as taking into account natural and climatic conditions and land reclamation indicators. This approach allowed the farm "smoothly" switching to resource-saving technology, the use of which ensured effective resource management, reduction of the negative load on the rice irrigation ecosystem, quality improvement of the obtained grain and the improvement of the land reclamation state within the land reclamation system (Tables 1-3).

Table 1. Biometric and quantitative characteristics of rice

\begin{tabular}{|c|c|c|c|c|c|}
\hline \multirow[t]{2}{*}{$\mathbf{n} / \mathbf{n}$} & Item & \multicolumn{4}{|c|}{ Year } \\
\hline & Vegetation period & & & & \\
\hline \multirow[t]{2}{*}{1} & - using new technology & 116 & 116 & 116 & 115 \\
\hline & - control & 119 & 117 & 118 & 117 \\
\hline \multirow{3}{*}{2} & Plant height, $\mathrm{cm}$ & & & & \\
\hline & - using new technology & 92.9 & 93.6 & 94.3 & 95.1 \\
\hline & - control & 86.5 & 87.2 & 85.8 & 87.2 \\
\hline \multirow{3}{*}{3} & Panicle length, $\mathrm{cm}$ & & & & \\
\hline & - using new technology & 16.4 & 16.5 & 17.1 & 17.0 \\
\hline & - control & 15.5 & 15.8 & 16.2 & 16.4 \\
\hline \multirow{3}{*}{4} & Number of spikelets in a panicle, pcs. & & & & \\
\hline & - using new technology & 197 & 198 & 205 & 204 \\
\hline & - control & 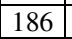 & 190 & 194 & 197 \\
\hline \multirow{7}{*}{5} & Number of grains, pcs.: & & & & \\
\hline & total & & & & \\
\hline & - using new technology & 193 & 195 & 198 & 200 \\
\hline & - control & 65 & 70 & 65 & 73 \\
\hline & blind seeds & & & & \\
\hline & - using new technology & 5 & 3 & 4 & 4 \\
\hline & - control & 2 & 3 & 2 & 2 \\
\hline \multirow{3}{*}{6} & Blind-seed disease, \% & & & & \\
\hline & - using new technology & 2.6 & 1.5 & 2.0 & 2.0 \\
\hline & - control & 3.1 & 4.3 & 3.1 & 2.8 \\
\hline \multirow{8}{*}{7} & Length-width ratio of the bruchid weevil (1/b) & 2.3 & 2.3 & 2.2 & 2.2 \\
\hline & Weight, g/plant: & & & & \\
\hline & grain & & & & \\
\hline & - using new technology & 7.7 & 7.8 & 7.9 & 8.0 \\
\hline & - control & 2.6 & 2.8 & 2.6 & 2.9 \\
\hline & straw & & & & \\
\hline & - using new technology & 7.2 & 7.3 & 7.4 & 7.4 \\
\hline & - control & 2.4 & 2.6 & 2.4 & 2.7 \\
\hline \multirow{3}{*}{9} & Straw : grain ratio & & & & \\
\hline & - using new technology & 0.91 & 0.87 & 0.86 & 0.85 \\
\hline & - control & 0.94 & 0.93 & 0.94 & 0.92 \\
\hline \multirow{3}{*}{10} & Thousand-kernel weight, $\mathrm{g}$ & & & & \\
\hline & - using new technology & 28.2 & 28.6 & 29.5 & 29.3 \\
\hline & - control & 26.8 & 26.5 & 27.2 & 27.4 \\
\hline 11 & $\begin{array}{l}\text { Average density of crops, plants } / 1 \mathrm{~m}^{2} \text { (using new technology) } \\
1 \text { plant per seedbed } \\
2 \text { plants per seedbed } \\
3 \text { plants per seedbed } \\
4 \text { plants per seedbed } \\
\text { control (average by years) }\end{array}$ & \multicolumn{4}{|c|}{$\begin{array}{c}25 \\
50 \\
75 \\
100 \\
360\end{array}$} \\
\hline 12 & Land use factor & \multicolumn{4}{|c|}{77.6} \\
\hline 13 & Yield (4 plants per seedbed), t/ha & 6.0 & 6.1 & 6.2 & 6.2 \\
\hline 14 & Yield (3 plants per seedbed), t/ha & 4.5 & 4.6 & 4.6 & 4.7 \\
\hline 15 & Yield (2 plants per seedbed), t/ha & 3.0 & 3.0 & 3.1 & 3.1 \\
\hline 16 & Yield (1 plant per seedbed), t/ha & 1.5 & 1.5 & 1.5 & 1.6 \\
\hline 17 & Yield, control & 9.1 & 9.8 & 9.1 & 10.2 \\
\hline
\end{tabular}


Table 2. Dynamics of soil reclamation condition on a test field in Chernoerkovskoye LLC of Slavyansky District with an area of 4.5 hectares for 2016-2019 when cultivating rice on underground drip irrigation under mulch perforated film

\begin{tabular}{|c|c|c|c|c|c|}
\hline $\mathrm{n} / \mathrm{n}$ & Item & Unit of measure & Year of study & Value & Assessment of soil reclamation \\
\hline 1 & 2 & 3 & 4 & 5 & 6 \\
\hline \multirow{8}{*}{1} & \multirow{8}{*}{$\begin{array}{l}\text { Groundwater level / Groundwater } \\
\text { mineralization }\end{array}$} & \multirow{8}{*}{$\mathrm{m} /(\mathrm{g} / \mathrm{l})$} & \multirow{2}{*}{2016} & 1.3 & \multirow{2}{*}{2} \\
\hline & & & & 3.13 & \\
\hline & & & \multirow{2}{*}{2017} & 1.4 & \multirow{2}{*}{2} \\
\hline & & & & 3.04 & \\
\hline & & & & 1.5 & \\
\hline & & & 2018 & 2.83 & 1 \\
\hline & & & & 1.6 & \\
\hline & & & 2019 & 2.65 & 1 \\
\hline \multirow{4}{*}{2} & \multirow{4}{*}{ Soil pH } & \multirow{4}{*}{-} & 2016 & 6.8 & 1 \\
\hline & & & 2017 & 7.0 & 1 \\
\hline & & & 2018 & 7.1 & 1 \\
\hline & & & 2019 & 7.1 & 1 \\
\hline & & & 2016 & 3.5 & 4 \\
\hline 3 & Humus content & $O$ & 2017 & 3.5 & 4 \\
\hline 3 & Humus content & $\%$ & 2018 & 3.7 & 4 \\
\hline & & & 2019 & 4.0 & 3 \\
\hline & & & 2016 & 188 & 4 \\
\hline & & & 2017 & 192 & 4 \\
\hline 4 & Humus reserves in a layer of $0-100 \mathrm{~cm}$ & t/ha & 2018 & 198 & 4 \\
\hline & & & 2019 & 204 & 3 \\
\hline & & & 2016 & 4.7 & 4 \\
\hline 5 & Hydrolyzable nitrogen (according to Tunin- & & 2017 & 4.9 & 4 \\
\hline 5 & Kononova) & mg/100 g & 2018 & 5.0 & 3 \\
\hline & & & 2019 & 5.2 & 3 \\
\hline ( & & & 2016 & 4.2 & 4 \\
\hline & & & 2017 & 4.6 & 4 \\
\hline 6 & Labile phosphorus (according to Chirikov) & $\mathrm{mg} / 100 \mathrm{~g}$ & 2018 & 4.9 & 4 \\
\hline & & & 2019 & 5.3 & 3 \\
\hline & & & 2016 & 2.9 & 4 \\
\hline 7 & & & 2017 & 3.6 & 4 \\
\hline 1 & Labile potassium (according to Chirikov) & $\mathrm{mg} / 100 \mathrm{~g}$ & 2018 & 4.0 & 4 \\
\hline & & & 2019 & 4.3 & 3 \\
\hline & & & 2016 & 11.8 & 4 \\
\hline 8 & & - & 2017 & 11.1 & 4 \\
\hline 8 & Nitrogen C:N & - & 2018 & 10.5 & 3 \\
\hline & & & 2019 & 9.8 & 3 \\
\hline & & & 2016 & 57 & 4 \\
\hline & & & 2017 & 61 & 3 \\
\hline 9 & Exchange magnesium content in soil (MgO) & $\mathrm{mg} / \mathrm{kg}$ of so1l & 2018 & 63 & 3 \\
\hline & & & 2019 & 68 & 3 \\
\hline & & & 2016 & 9.1 & 4 \\
\hline & & & 2017 & 9.8 & 4 \\
\hline 10 & Sulphate (labile) sulfur content, S & $\mathrm{mg} / \mathrm{kg}$ of so1l & 2018 & 10.7 & 3 \\
\hline & & & 2019 & 11.2 & 3 \\
\hline & & & 2016 & 35 & 4 \\
\hline 11 & Deoree of hase caturation $\mathrm{V}$ & $o r$ & 2017 & 39 & 4 \\
\hline 11 & Degree of base saturation, V & $\%$ & 2018 & 45 & 3 \\
\hline & & & 2019 & 51 & 3 \\
\hline & & & 2016 & 0.92 & 4 \\
\hline 12 & Structural Factor $\mathrm{K}$ & & 2017 & 0.96 & 4 \\
\hline 12 & Structural Factor, $K_{\text {str }}$ & - & 2018 & 1.11 & 3 \\
\hline & & & 2019 & 1.23 & 3 \\
\hline & & & 2016 & 50 & 4 \\
\hline 13 & Total norocity & 0 & 2017 & 54 & 3 \\
\hline 13 & Total porosity & $\%$ & 2018 & 59 & 2 \\
\hline & & & 2019 & 64 & 2 \\
\hline & & & 2016 & 1.43 & 4 \\
\hline 14 & Soil dencity (according to N A Kachingky) & $\mathrm{cm}^{3}$ & 2017 & 1.39 & 3 \\
\hline 14 & Soil density (according to N.A. Kachinsky) & $\mathrm{g} / \mathrm{cm}^{3}$ & 2018 & 1.35 & 3 \\
\hline & & & 2019 & 1.29 & 2 \\
\hline & & & 2016 & 18.0 & 4 \\
\hline 15 & & & 2017 & 24.0 & 3 \\
\hline 15 & Soil nitrification capacity & $\mathrm{mg} \mathrm{NO}_{3} / \mathrm{kg}$ & 2018 & 28.0 & 3 \\
\hline & & & 2019 & 33.0 & 2 \\
\hline & & & 2016 & 28 & 4 \\
\hline & Content of water-carrying aggregates in the & $o$ & 2017 & 34 & 3 \\
\hline 16 & layer of $0-30 \mathrm{~cm}$ & $\%$ & 2018 & 38 & 3 \\
\hline & & & 2019 & 43 & 2 \\
\hline 17 & Salt content/Salinity Tyne & $\% /-$ & 2016 & 1.1 & 3 \\
\hline & & $\% 1-$ & 2010 & & loride-sulfate \\
\hline
\end{tabular}




\begin{tabular}{|c|c|c|c|c|c|}
\hline & & & \multirow{2}{*}{2017} & 1.1 & 3 \\
\hline & & & & \multicolumn{2}{|c|}{ chloride-sulfate } \\
\hline & & & \multirow{2}{*}{2018} & 1.0 & 2 \\
\hline & & & & \multicolumn{2}{|c|}{ chloride-sulfate } \\
\hline & & & \multirow{2}{*}{2019} & 0.8 & 2 \\
\hline & & & & \multicolumn{2}{|c|}{ chloride-sulfate } \\
\hline \multirow{4}{*}{18} & \multirow{4}{*}{$\begin{array}{l}\text { Total effect of toxic } \mathrm{CO}_{3}{ }^{2-}, \mathrm{HCO}_{3}{ }^{-}, \mathrm{Cl}^{-}, \mathrm{SO}_{4}{ }^{2-} \\
\text { (N.I. Bazilevich, E.I. Pankova) }\end{array}$} & \multirow{4}{*}{ mg-eq $\mathrm{Cl}^{-}$} & 2016 & 1.20 & 3 \\
\hline & & & 2017 & 1.00 & 2 \\
\hline & & & 2018 & 0.90 & 2 \\
\hline & & & 2019 & 0.80 & 2 \\
\hline \multirow{4}{*}{19} & \multirow{4}{*}{ Soil $\mathrm{CO}_{2}$ emission rate } & \multirow{4}{*}{$\mathrm{mg} \mathrm{CO}_{2} / 10 \mathrm{~g} /$ day } & 2016 & 9.8 & 4 \\
\hline & & & 2017 & 10.3 & 3 \\
\hline & & & 2018 & 10.9 & 3 \\
\hline & & & 2019 & 11.8 & 3 \\
\hline \multirow{21}{*}{20} & \multicolumn{5}{|l|}{ Micronutrient content } \\
\hline & \multirow{4}{*}{ Manganese $(\mathrm{Mn})\left(\right.$ in $\left.0.1 \mathrm{H}_{2} \mathrm{O}_{4}\right)$} & \multirow{20}{*}{$\mathrm{mg} / \mathrm{kg}$ of soil } & 2016 & 18 & 0.8 \\
\hline & & & 2017 & 21 & 0.6 \\
\hline & & & 2018 & 23 & 0.6 \\
\hline & & & 2019 & 25 & 0.6 \\
\hline & \multirow{4}{*}{ Copper $(\mathrm{Cu})($ in $0.1 \mathrm{KCl})$} & & 2016 & 1.40 & 0.8 \\
\hline & & & 2017 & 1.70 & 0.6 \\
\hline & & & 2018 & 1.90 & 0.6 \\
\hline & & & 2019 & 2.20 & 0.6 \\
\hline & \multirow{4}{*}{ Zinc $(\mathrm{Zn})$ (in $0.1 \mathrm{KCl}$ ) } & & 2016 & 0.90 & 0.8 \\
\hline & & & 2017 & 1.20 & 0.6 \\
\hline & & & 2018 & 1.40 & 0.6 \\
\hline & & & 2019 & 1.60 & 0.6 \\
\hline & \multirow{4}{*}{ Cobalt $(\mathrm{Co})$ (in $0.1 \mathrm{HNO}_{3}$ ) } & & 2016 & 1.00 & 0.8 \\
\hline & & & 2017 & 1.20 & 0.8 \\
\hline & & & 2018 & 1.40 & 0.8 \\
\hline & & & 2019 & 1.60 & 0.6 \\
\hline & \multirow{4}{*}{ Molybdenum (Mo) (in oxalate extract) } & & 2016 & 0.14 & 0.8 \\
\hline & & & 2017 & 0.17 & 0.8 \\
\hline & & & 2018 & 0.19 & 0.8 \\
\hline & & & 2019 & 0.21 & 0.6 \\
\hline & \multirow{8}{*}{ Total points } & \multirow{8}{*}{-} & \multirow{2}{*}{2016} & \multicolumn{2}{|c|}{73} \\
\hline & & & & \multicolumn{2}{|c|}{ satisfactory } \\
\hline & & & & & \\
\hline & & & 2017 & & \\
\hline & & & 2018 & & \\
\hline & & & 2018 & & \\
\hline & & & 2010 & & \\
\hline & & & 2019 & & \\
\hline
\end{tabular}

Assessment of soil reclamation condition was performed according to soil reclamation condition scale (Figure 4).

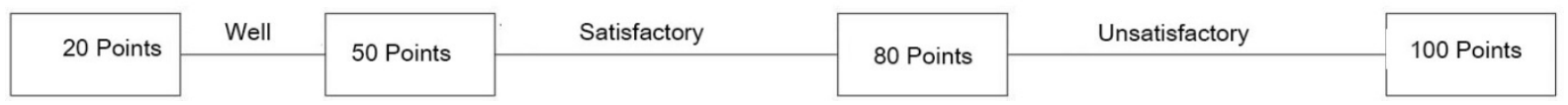

Figure 4. Scale of quantitative assessment of soil reclamation condition on rice check

Tables 1 and 2 show that the use of the new resourcesaving technology of underground rice drip irrigation on rice irrigation systems for rice cultivation under polyethylene and/or mulch perforated film has improved the biometric and quantitative characteristics of rice in comparison with the traditional farm technology (control), and made it possible to improve the land reclamation state from "satisfactory" to "good".

\section{Conclusion}

The developed resource-saving technology of rice cultivation on drip watering under mulch film allows cultivating elite rice varieties, which do not only ensure $100 \%$ of the farm's own needs in the sown material, but also allows obtaining a super profit from its implementation.

Rice cultivation without creating a layer of water on a rice check (traditional technologies) made it possible to use new generation rice crop rotations with the inclusion of cucurbits and vegetables, which fundamentally changes the established rules for their formation. Such crop rotations are the basis for the sustainable development of the rice sector of Russia, which will help not only to take into account all environmental reclamation requirements for rice production, but also to strengthen Russia's food security.

The use of drip irrigation in rice cultivation is a relevant and promising area, the development of which will allow abandoning the construction of new or expensive reconstruction and operation of existing rice irrigation systems and cultivating rice on any agricultural land.

The main indicators of efficiency of the proposed method are as follows:

- annual average reduction of the irrigation norm by 5 times with respect to the traditional technology of rice cultivation by flooding;

- improvement of soil reclamation from 
"satisfactory" in 2016 to "good" in 2019;

- reduction of labor intensity by $42 \%$; $36 \%$

- reduction of rice production costs by an average of

- reduction of doses of macro- and micronutrient inputs on average by $28 \%$.

\section{References}

1. S. S. Girsang, Jr. T. Q. Correa, J. R. Quilty, P. B. Sanchez, R. J. Buresh Soil and Tillage Research, 202, 104647

(2020) doi.org/10.1016/j.still.2020.104647.

2. G. Arbat, S. Cufí, M. Duran-Ros, J. Pinsach, J. Puig-Bargués, J. Pujol, F.R. de Cartagena Water (Switzerland), 12 (6), 1724 (2020).

3. H. Chen, W. Zeng, Y. Jin, Y. Zha, B. Mi, S. Zhang Journal of Hydrology, 591, 125325 (2020).

4. S. Majumder, P. Banik, Journal of Environmental Management, 279, $111620 \quad$ (2021) doi.org/10.1016/j.jenvman.2020.111620.

5. Z. Chen, P. Li, S.Jiang, H. Chen, J. Wang, C. Cao, Science of The Total Environment 757, 143748 (2021).

6. R. Joshia, B. Singh, A. Shukla, Current Plant Biology, 13, 45-52 (2018) doi.org/10.1016/j.cpb.2018.05.001.

7. M. A. BritoPinto, J. M. BarbatParfitt, L. C. Timm, L. C. Faria, G. Concenço, L. Stumpf, B. F. Nörenberg, Field Crops Research, 248, 107714 (2020) doi.org/10.1016/j.fcr.2020.107714.

8. F. Monaco, G. Sali, Agricultural Water Management, 195, 47-57 (2018).

9. D. P. Patel, A. Dasb, G. C. Munda, P.K. Ghosh, J. S. Bordoloi, M. Kumar, Agricultural Water Management, $97 \quad$ (9), $1269-1276 \quad$ (2010) doi.org/10.1016/j.agwat.2010.02.018.

10. A. López-Piñeiro, D. Peña, A. Albarrán, J. Sánchez-Llerena, D. Becerra, D. Fernández, S. Gómez, Journal of Environmental Management, 237, 44-53

(2019) doi.org/10.1016/j.jenvman.2019.02.058.

11. P. Vijayaraghavareddy, Y. Xinyou, P. C. Struik, U. Makarla, Sreeman Sh., Rice Science, 27 (4), 345-354 doi.org/10.1016/j.rsci.2020.05.009.

12. M. D. M. Kadiyala, J. W. Jones, R. S. Mylavarapu, Y. C. Li, M. D. Reddy, Agricultural Water Management, 149, 23-32 (2015) doi.org/10.1016/j.agwat.2014.10.019.

13. S. F. Islam, B. O. Sander, J. R. Quilty, A. Neergaard, J. W. Groenigen, L. S. Jensen, Science of The Total Environment, 739, 140215 (2020) doi.org/10.1016/j.scitotenv.2020.140215.

14. M. Ishfaq, N. Akbar, Sh. A. Anjum, M. A. Growth, Journal of Integrative Agriculture 19 (11), 2656-2673 (2020).

15. I.P. Kruzhilin, M.A. Ganiev, V.V. Melikhov, K.A. Rodin, S.D. Fomin, N.N. Dubenok IOP Publishing IOP Conf. Series: Earth and Environmental Science $341012100 \quad$ (2019) doi:10.1088/1755-1315/341/1/012100/.
16. I.P. Kruzhilin, S.D. Fomin, T.A. Gamm, A.A. Mushinskiy IOP Publishing IOP Conf. Series: Earth and Environmental Science 350012037 (2019) doi:10.1088/1755-1315/350/1/012037.

17. I.P. Kruzhilin, A.S. Ovchinnikov, N.V. Kuznetsova, O.V. Kozinskaya, S.D. Fomin, V.S. Bocharnikov, E.S. Vorontsova, Journal of Engineering and Applied Sciences. 13 (13), 41814184

https://arpnjournals.org/jeas/research_papers/rp_2 018/jeas_0718_7186.pdf.

18. I.P. Kruzhilin, M.A. Ganiev, V.V. Melikhov, K.A. Rodin, N.N. Dubenok, A.S. Ovchinnikov, S.D. Fomin, N.M. Abdou ARPN Journal of Engineering and Applied Sciences, 12 (24), 71187123 (2017.) https://www.researchgate.net/publication/3224185 63 Mode_of_rice drip_irrigation.

19. T. Safronova, S. Vladimirov, I. Prikhodko IOP Conf. Series: Earth and Environmental Science $666042063 \quad$ (2021) doi:10.1088/17551315/666/4/042063.

20. T. Safronova, S. Vladimirov, I Prikhodko E3S Web Conf., 175, $09011 \quad$ (2020) https://doi.org/10.1051/e3sconf/202017509011. 